\title{
論 文 Estimation of slope and three-dimensional diagrams using TIN : - Comparison of various methods for entering elevation levels-
}

\author{
Nobuyuki $\mathrm{ABE}^{*}$
}

\begin{abstract}
$\mathrm{ABE}$, Nobuyuki : Estimation of slope and three-dimensional diagrams using TIN : Comparison of various methods for entering elevation levels. Jpn. J. For. Plann. 23 : 1 9, 1994 Data entry is usually the major bottleneck in GIS implementation. The position and elevation of contour lines must be entered to estimate slope degree and to make three-dimensional diagrams. Entering digital data requires considerable time and labor. This study examines various methods of entering elevation values. Slope degree and the three-dimensional diagrams generated from the Triangular Irregular Network are examined in the cases of 10,20 , and 50 meter contour intervals and contrasted with the case of a 50 meter grid interval (point method). From the practical viewpoint of relative ease and efficiency of data entry, differences in slope degree and the three-dimensional diagrams of the 10 and 20 meter cases are not important. Big differences, however, are visible between the 20 and 50 meter contour interval cases. Much labor is required to enter the elevation values with the point method. So, for practical purposes, a 20 meter contour interval is considered good.
\end{abstract}

阿部信行 : TINを利用した傾斜角区分および 3 次元図の作成一標高値の入力方法による 比較一 森林計画誌 $23: 1 \sim 9 ， 1994$ TINを利用して, 傾斜角区分や 3 次元図を作 成するためには，標高值を入力しなければならない。この標高値入力は手間がかかり，G

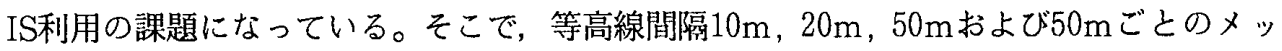
シュ交点（ポイント法と称す）の標高值を入力し, 傾斜角区分および 3 次元図を作成して, 実用的な入力方法を検討した。その結果，等高線間隔が $10 \mathrm{~m}$ と $20 \mathrm{~m}$ では，傾斜角区分およ び 3 次元図も注とんど差は認められないが，20m間隔と50m間隔では，傾斜角区分扮よび 3 次元図ともかなり異なった。一方, ポイント法は標高値の入力が等高線よりも煩雑であ る。従って，標高值は等高線間隔 $20 \mathrm{~m}$ を用いて入力するのが実用的な方法であると考えら れた。

\section{I . Introduction}

For a Geographic Information System (GIS) to be useful, it must receive and produce information effectively. To provide more practical information about thinning operations, I previously proposed a GIS System that incorporated ARC/INFO (Abe, 1993). Estimation of slope and three-dimensional diagrams using a GIS are very useful in forest management. Data entry, however, is usually a major bottleneck in implementing a GIS.

It is necessary to enter the position and elevation of contour lines to better utilize three-dimensional diagrams; but, this requires much time and labor. Using wide-spaced intervals between contour lines helps reduce input labor. But, there is a reduction in the relative precision with which slope can be estimated. So, I examined a practical method for

* Fac. of Agric., Niigata Univ., Niigata 950-21 新潟大学農学部 


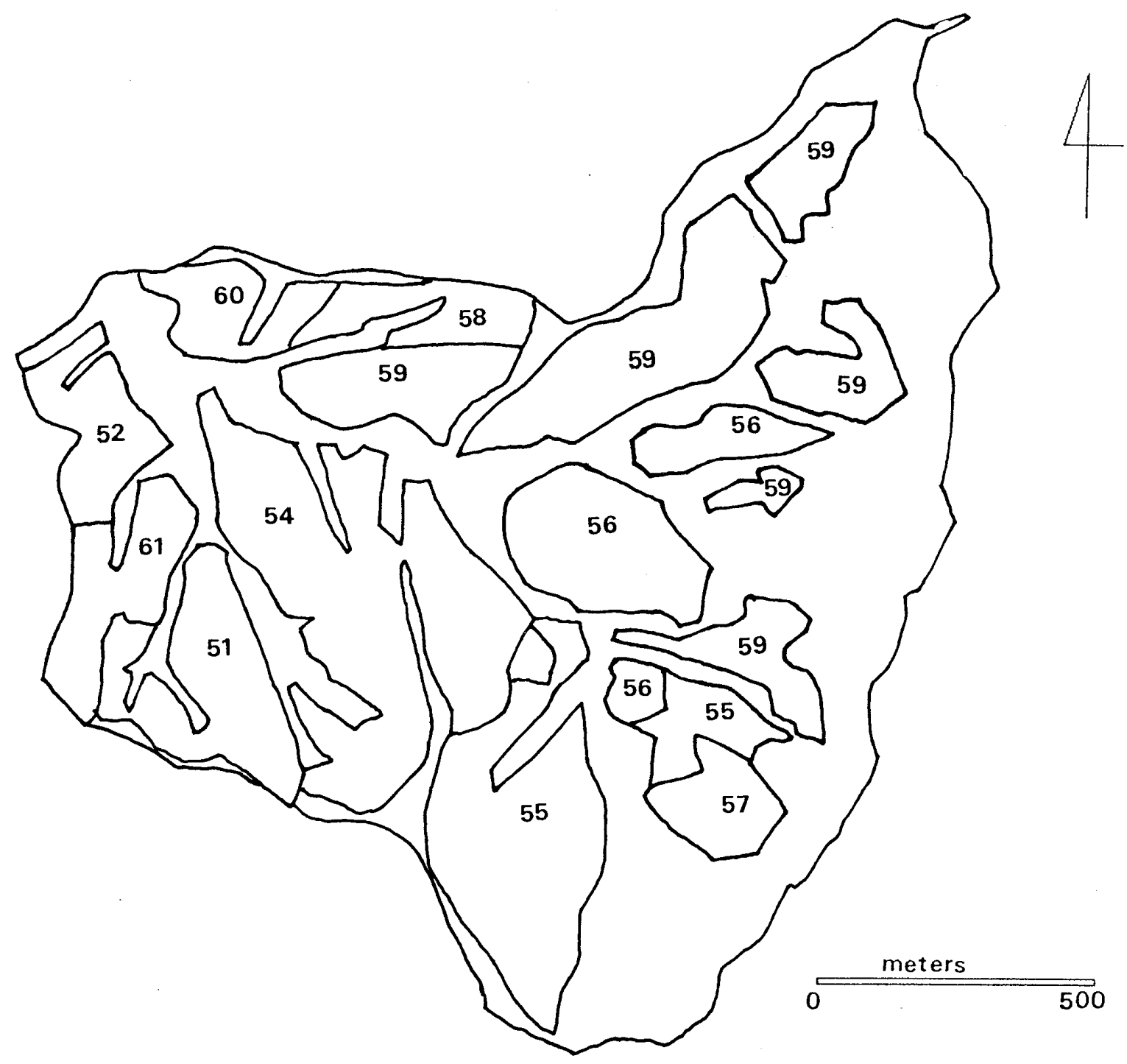

Fig.1 Map of the experimental sites with sub-compartments numbered.

determining an effective contour line interval.

\section{Study Area and Methods}

Studies were made in the 71 compartments of the Iwamizawa Management Area of the Hokkaido Prefectural Forest (Fig.1). The GIS was applied to 230 hectares using a scale of 1:5,000 and a $10 \mathrm{~m}$ contour interval. The software generating the three-dimensional diagram is called the Triangular Irregular Network (TIN) (ESRI,TIN, Ver.3.01,1989). A TIN models the terrain surface as a set of interconnected triangular facets where terrain parameters like slope and aspect are calculated and stored as attributes for each facet just as attributes are stored for polygons.

Since digital terrain data are usually provided as contours or regular grids, I examined the results of estimating the degree of slope and the three-dimensional diagrams from the digital elevation data. This approach compares contour intervals against intervals of a $50 \mathrm{~m}$ grid(called a "point method") using the relative ease and efficiency of data entry as the practical comparative criterion. Contour position and the regular grid are manually digitized and the cursor position is accurately measured by the digitizer to generate 


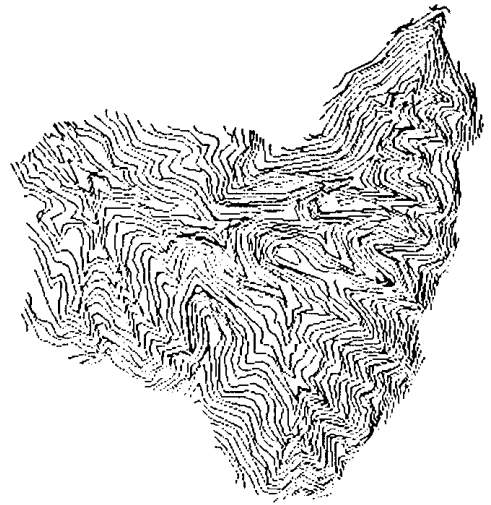

A

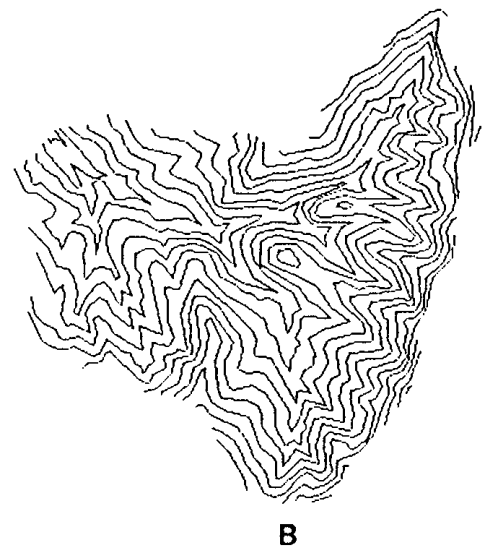

$\mathrm{A}: 10 \mathrm{~m}$ interva

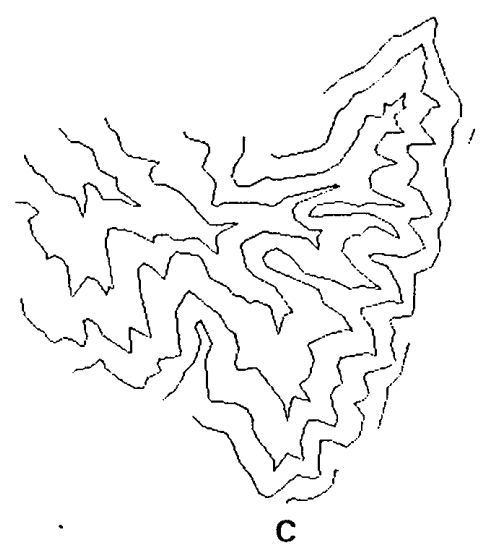

C: $50 \mathrm{~m}$ interval

Fig.2(1) Contour line diagrams

B: $20 \mathrm{~m}$ interval

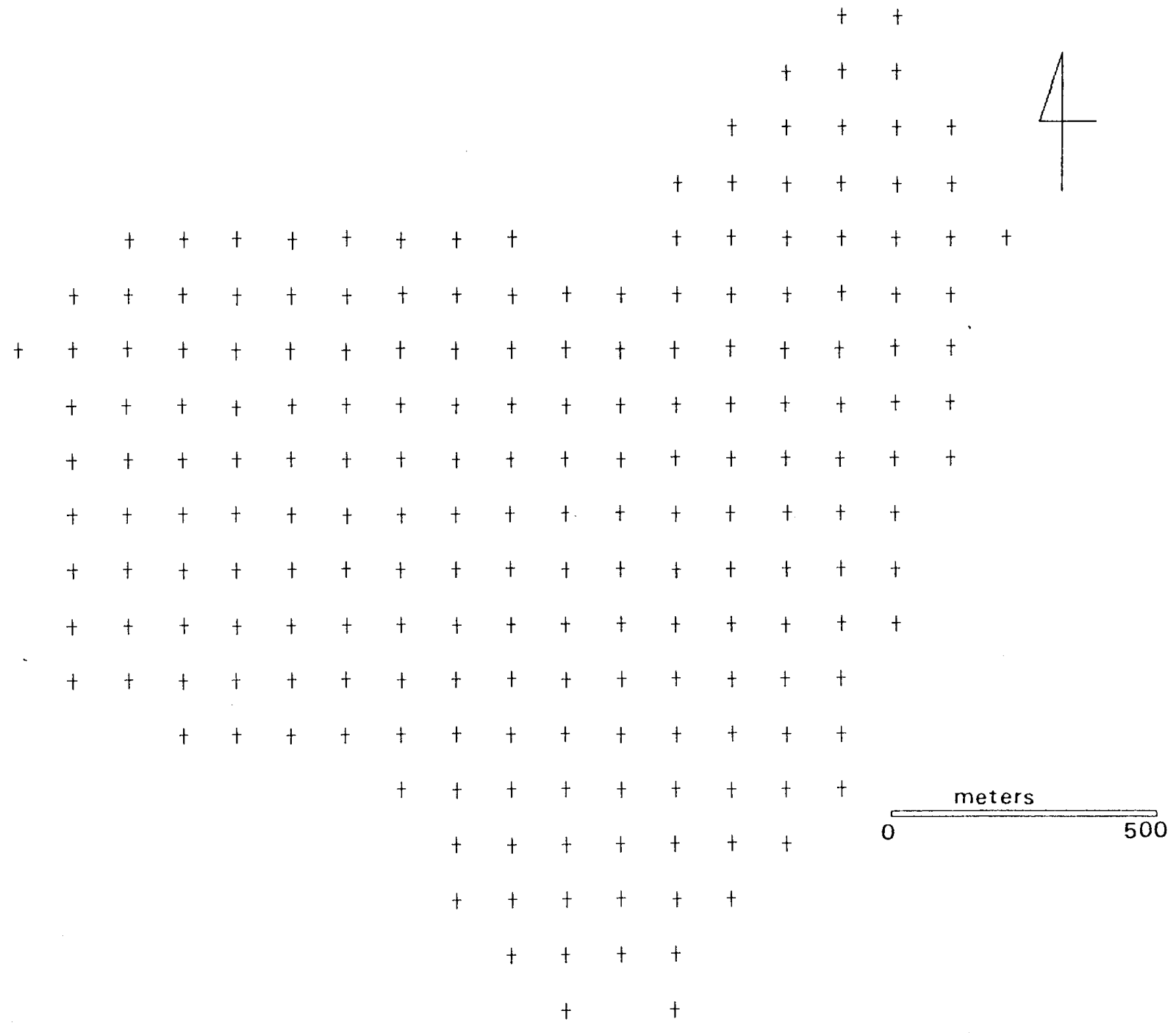

Fig.2(2) Regular grid network (50 m interval) 
Jpn. J. For. Plann. 23 '94

and enter the coordinate data in digital form. Elevation values are entered using a keyboard.

Contour intervals of 10,20 , and 50 meters are compared to a regular grid interval of $50 \mathrm{~m}$ [Fig.2(1) and Fig.2(2)]. Since a filter must be used to show the occurrence of zero slope (ESRI,1989), I used one filter for each of the three contour intervals and one for the point method.

\section{Results and Discussion}

1. Efficiency of entering the contour line and a regular grid position

It is very difficult to enter the position of contour lines in the $10 \mathrm{~m}$ case, because the intervals are narrow [see Fig.2(1)]. In the $20 \mathrm{~m}$ case the number of contours is half that of the $10 \mathrm{~m}$ case, making contour position entry easier. In the $50 \mathrm{~m}$ case, because the intervals are much wider, position entry is very easy.

Similarly, it is difficult to enter position data when the grid is narrow due to the tedious nature of moving the cursor. Therefore, after selecting the contour and grid, elevation values were input using a keyboard. When selecting the interval, there is no error at $20 \mathrm{~m}$ or more. It is impractical, however, because the point method is troublesome when selecting each grid. Practically, then, en-

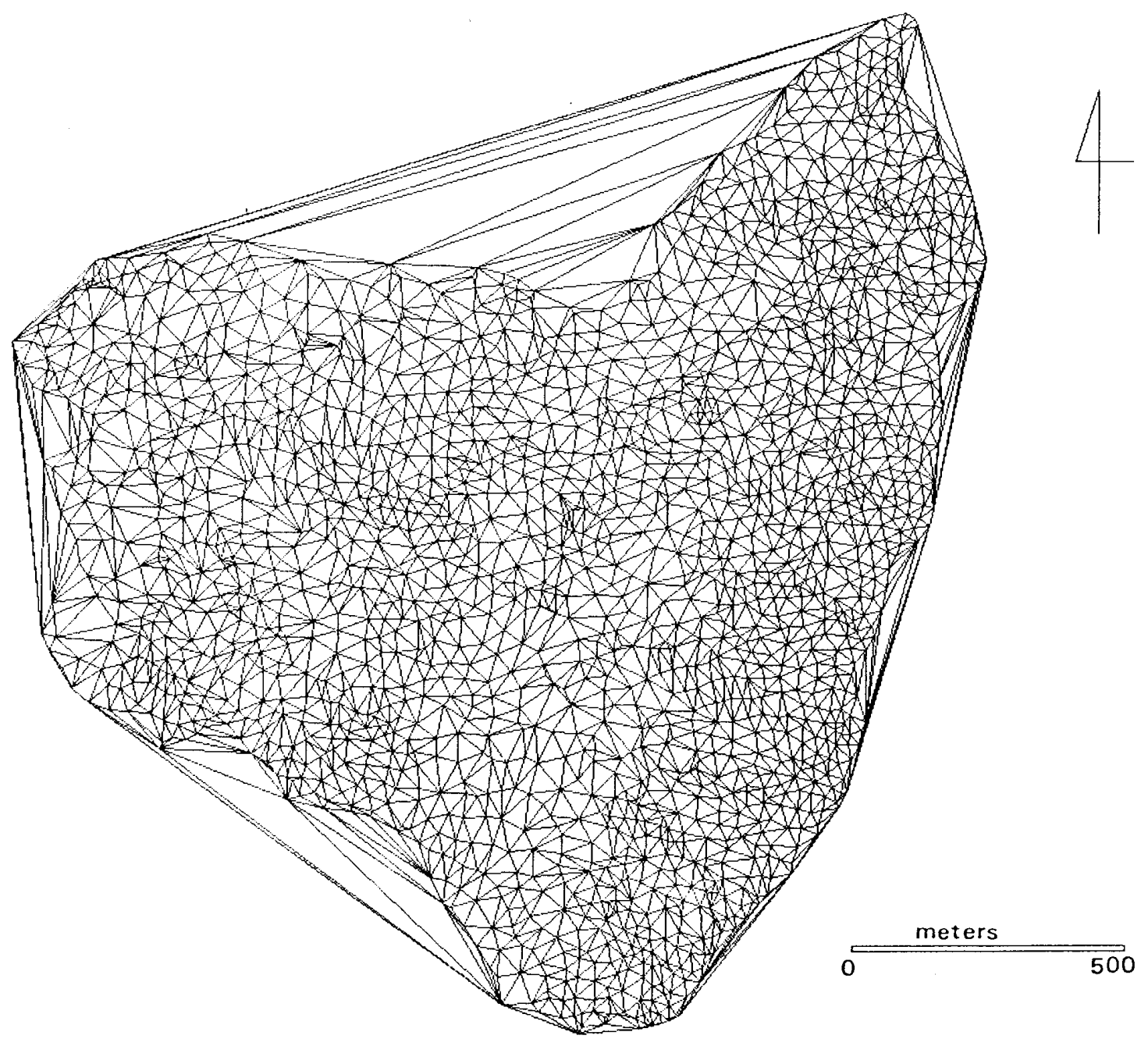

Fig.3(1) Polygons generated from $20 \mathrm{~m}$ contour lines using Triangular Irregular Network before applying one filter 


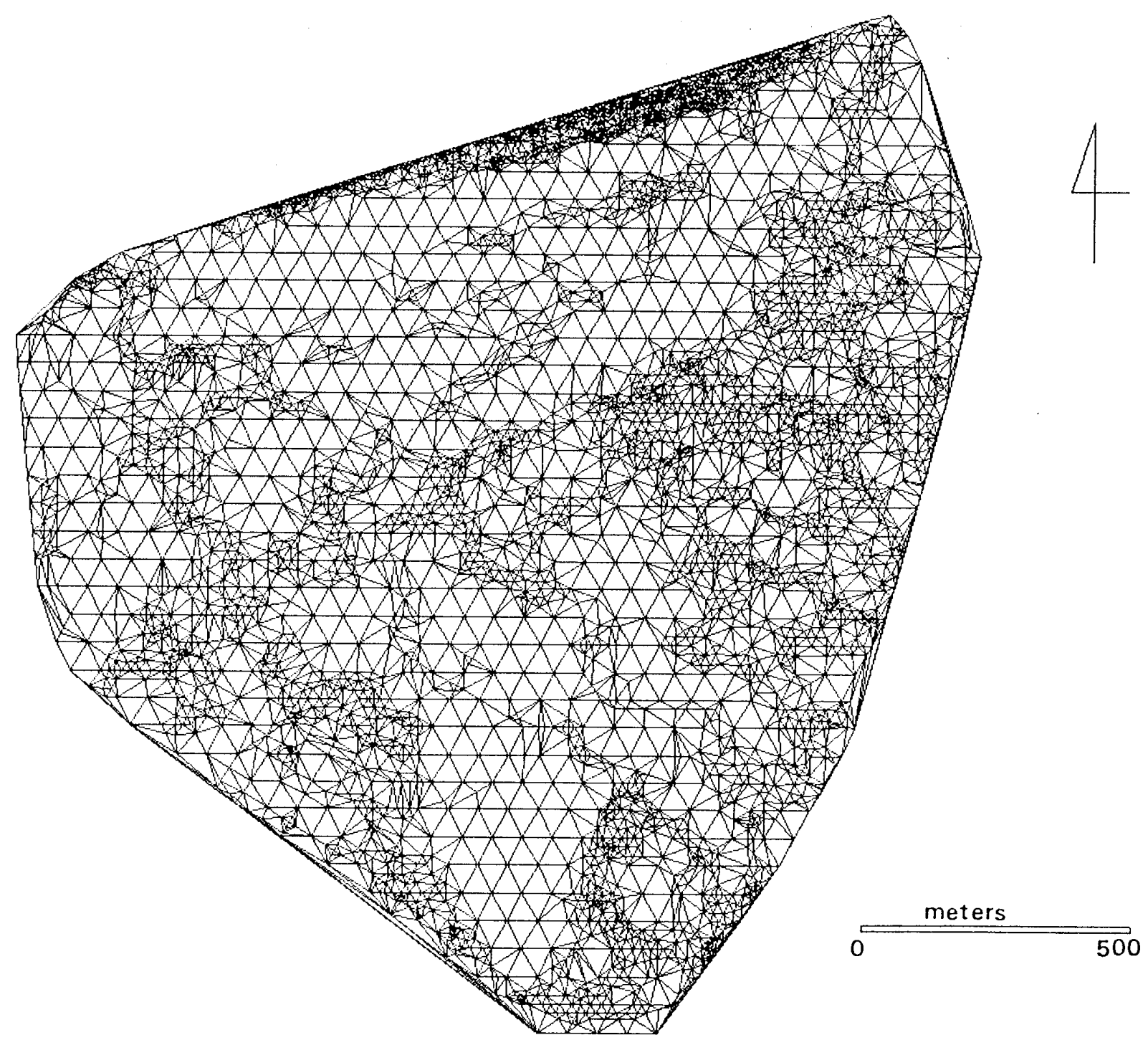

Fig.3(2) Triangular Irregular Network of Fig.3(1) after applying one filter

tering the contour position in the $20 \mathrm{~m}$ case is better than with $10 \mathrm{~m}$ intervals using the point method.

\section{Estimation of slope degree}

The TIN is a vector-based topological data model that is used to represent terrain data. A TIN represents the terrain surface as a set of interconnected triangular facets [Fig.3 (1)-before filtering and Fig.3 (2)-after filtering]. For each of the three vertices, the $X Y$ coordinate (geographic location) and the $\mathrm{Z}$ coordinate(elevation) values are encoded (ESRI,1989).
Entering narrow contours causes selection of a small cell size, and generates a large data file. Thus, areas with low spatial variability, such as gentle terrain, use more cells than are actually needed. Conversely, entering wide contours, causes selection of a large cell size and generates a smaller data file. The grid lines, however, may not be sufficiently fine to capture the detail in highly variable terrain.

The results of estimating the degree of slope using each contour interval and the regular grid for the study area are shown in 
Jpn. J. For. Plann. 23 '94

Table 1. Results of estimating the degree of slope in the study area using the Triangular Irregular Network

-Percentage of whole area-

\begin{tabular}{ccccc}
\hline $\begin{array}{l}\text { Estimated Slope } \\
\text { Class (degrees) }\end{array}$ & \multicolumn{3}{c}{ Interval of Contour } & Point \\
& $10 \mathrm{~m}$ & $20 \mathrm{~m}$ & $50 \mathrm{~m}$ & Method \\
\hline $0 \sim 5$ & $1.1 \%$ & $3.2 \%$ & $10.0 \%$ & $1.1 \%$ \\
$5 \sim 10$ & 3.1 & 5.2 & 8.5 & 5.8 \\
$10 \sim 15$ & 7.9 & 8.5 & 9.4 & 12.2 \\
$15 \sim 20$ & 14.2 & 13.7 & 12.6 & 20.0 \\
$20 \sim 25$ & 20.3 & 17.4 & 16.5 & 19.8 \\
$25 \sim 30$ & 19.3 & 18.6 & 15.7 & 15.4 \\
$30 \sim 35$ & 15.3 & 14.2 & 12.3 & 10.7 \\
$35 \sim 40$ & 10.0 & 9.7 & 7.3 & 6.7 \\
$40 \sim 45$ & 6.0 & 5.2 & 3.8 & 3.4 \\
$45 \sim 50$ & 1.7 & 2.3 & 2.0 & 1.3 \\
$50 \sim$ & 1.1 & 2.1 & 1.8 & 3.5 \\
\hline
\end{tabular}

Table 1. Slopes of 15 degrees or less increase as a percent of the total area approximately proportional to an increase in the contour interval. The point method showed that the percentage of the whole area belonging to slope classes from $0 \sim 15$ increased. In the case of steep slopes, however, contour intervals between $10 \mathrm{~m}$ and $20 \mathrm{~m}$ show no important change in the percent of the whole area each class occupies. For example, the 25 30 degree slope class with a $10 \mathrm{~m}$ contour interval occupies $19.3 \%$ of the whole area. A $20 \mathrm{~m}$ interval occupies $18.6 \%$, while a $50 \mathrm{~m}$ interval registers a decrease to $15.7 \%$ of the total area. Steeper slopes up to the $40 \sim 45$ degree class show the same tendency. From a practical viewpoint, then, differentiating between $10 \mathrm{~m}$ and $20 \mathrm{~m}$ contour intervals when predicting the degree of slope is not meaningful.

\section{A three-dimensional diagram}

Three-dimensional diagrams using each contour interval and the point method are shown in Fig.4(1) (4). The diagrams are less well differentiated in proportion to increasing contour interval width. In the $50 \mathrm{~m}$ case, the three-dimensional diagram is less clear than diagrams using either $10 \mathrm{~m}$ or $20 \mathrm{~m}$. Further, the $50 \mathrm{~m}$ interval produces a flat spot [Fig. 4(3)-lower center foreground] that does not actually exist and which does not appear in any of the other diagrams.

\section{Practical method for entering elevation value}

When considering the $10 \mathrm{~m}$ and $20 \mathrm{~m}$ cases, there are no practical differences in estimated slope degree and the three-dimensional diagrams. But, we see a big difference between the $20 \mathrm{~m}$ and $50 \mathrm{~m}$ cases. Contour position entry becomes easier as the contour interval increases. However, accuracy of predicted slope degree using three-dimensional diagrams decreases in the $50 \mathrm{~m}$ case. Conversely, the accuracy of predicted slope degree varied using the point method which also requires considerable labor to enter the elevation value. Thus, for practical use, a $20 \mathrm{~m}$ contour interval is considered best.

Data entry using scanning is claimed to be five to 10 times faster than digitizing. But, 


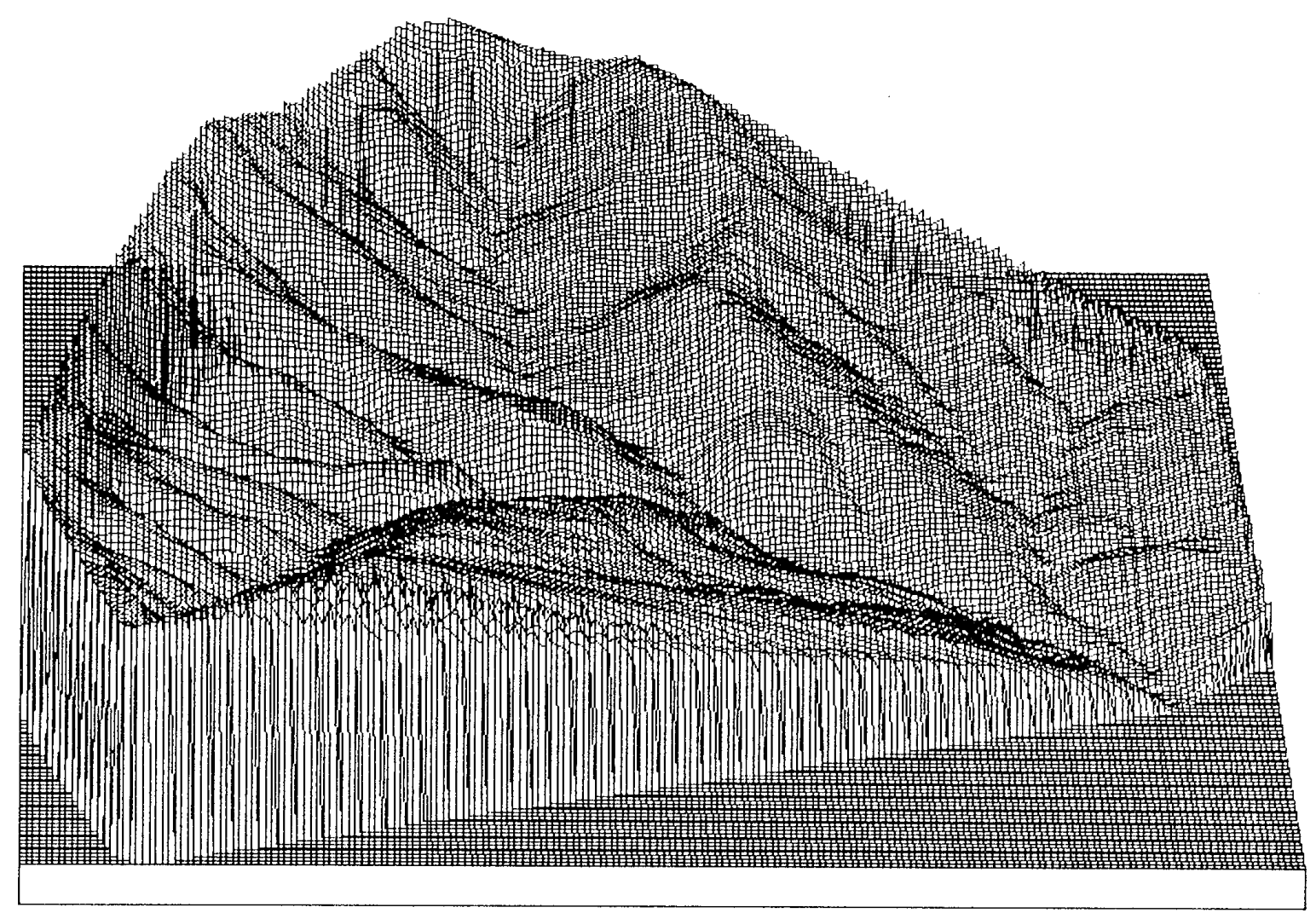

Fig.4(1) Three-dimensional diagram: $10 \mathrm{~m}$ contour interval

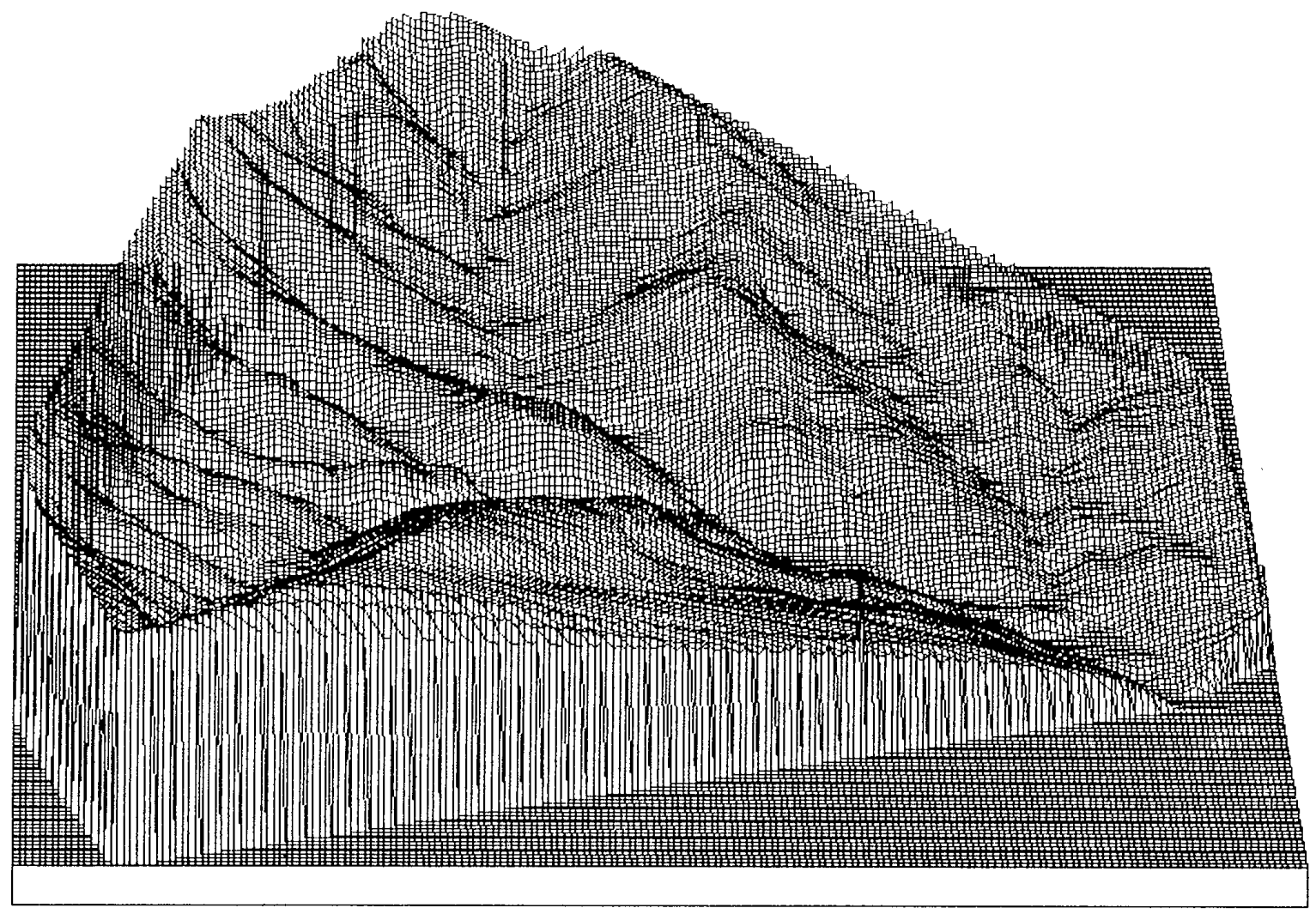

Fig.4(2) Three-dimensional diagram: $20 \mathrm{~m}$ contour interval 
Jpn. J. For. Plann. 23 '94

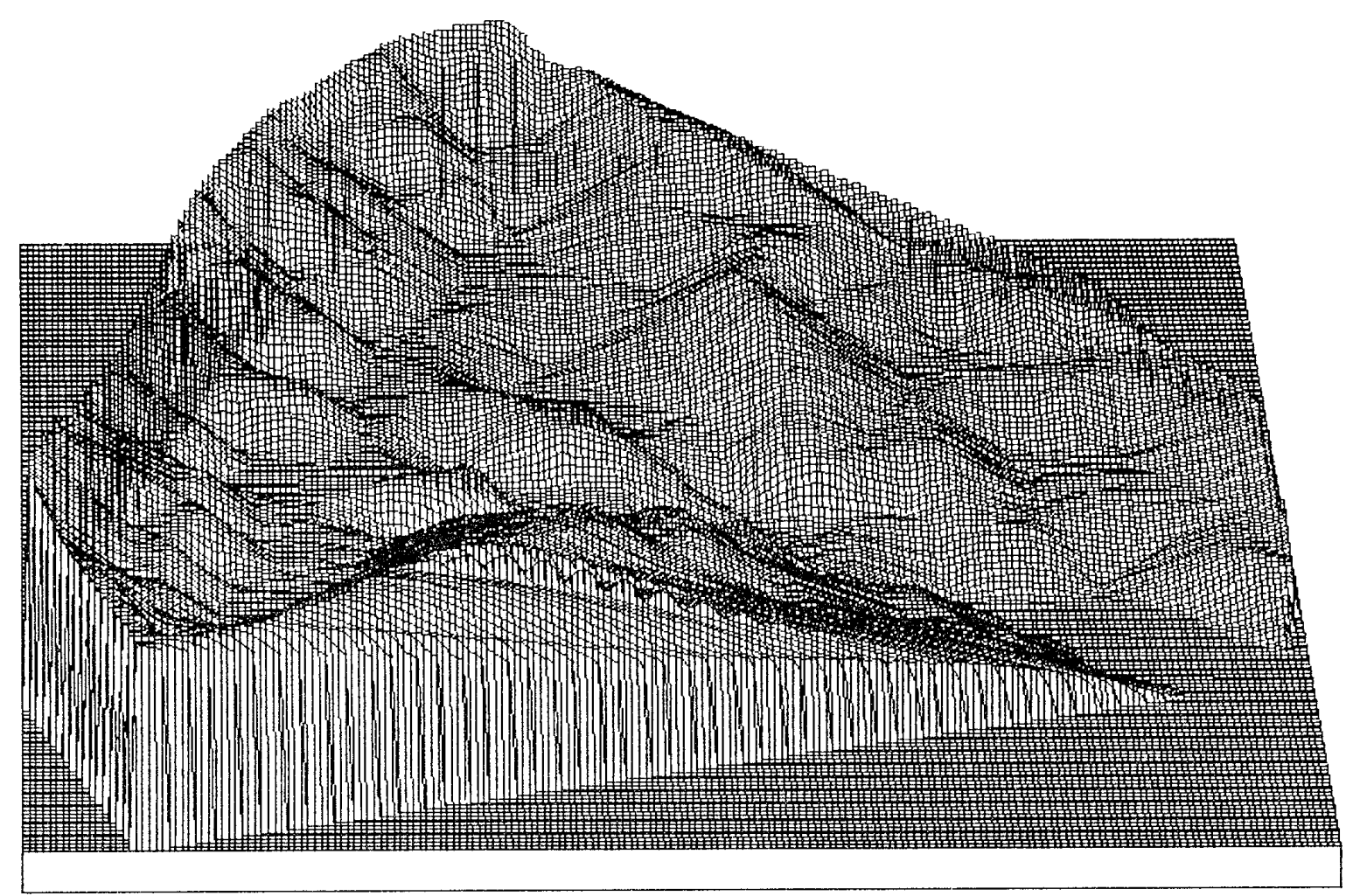

Fig.4(3) Three-dimensional diagram: $50 \mathrm{~m}$ contour interval

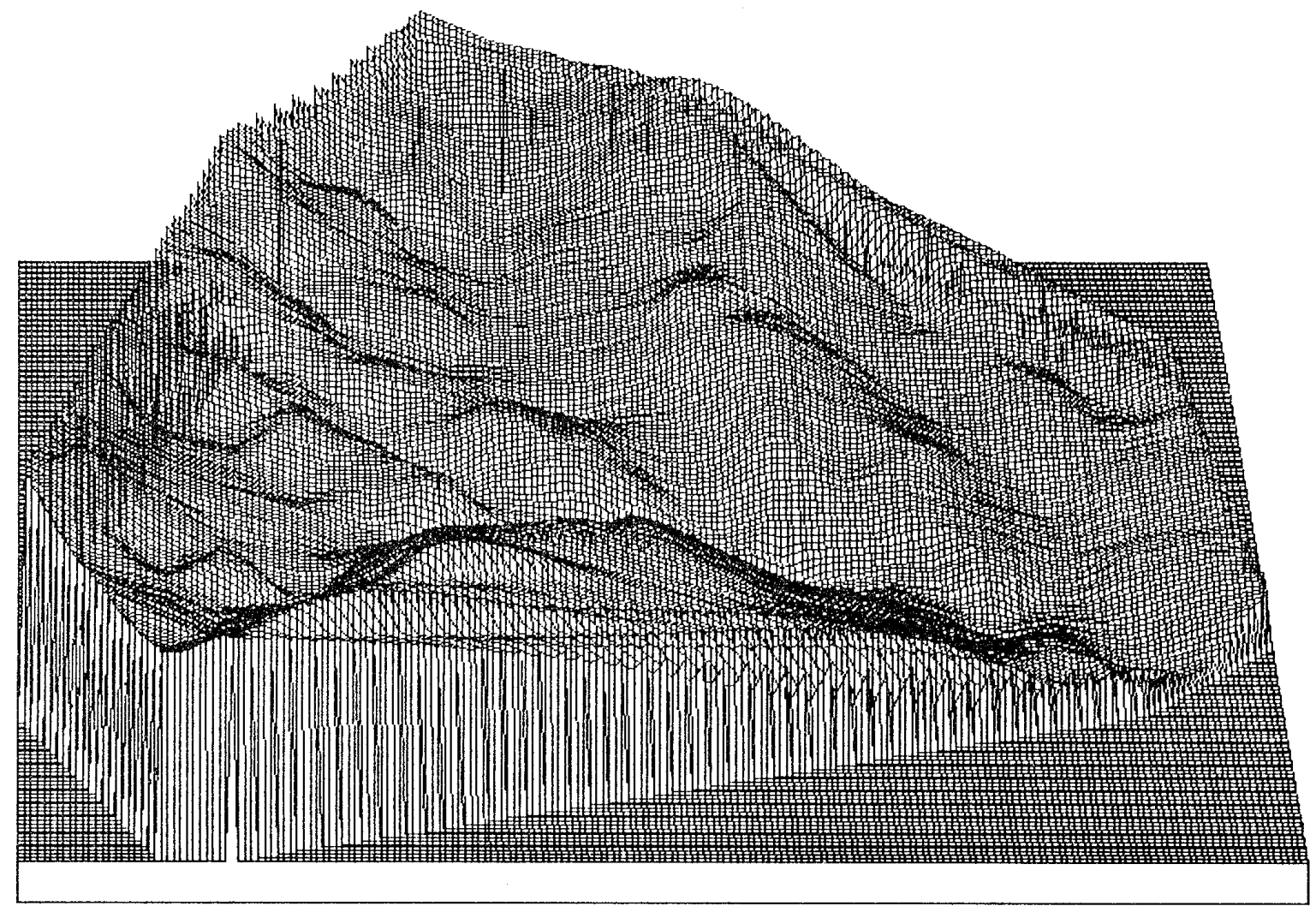

Fig.4(4) Three-dimensional diagram using the point method 
scanning works best with maps that are very clean and simple and without extraneous information such as text or graphic symbols (Aronoff,1989). Therefore, manual digitizing is the most widely used method for entering data from maps.

\section{Acknowledgments}

The author thanks Miss Akiko Kurihara, Pasco Corporation for her valuable advice and helpful suggestions in using the TIN .

\section{Literature cited}

ABE, N. (1993) Support system using Geographic Information System for thinning operations in todomatsu stand. J. Jpn. For. Soc. $75: 501 \sim 510$. (in Japanese with English summary)

ARONOFF, S. (1989) Geographic Information Systems. 294pp, WDL Publications, Ottawa. ESRI(Environmental Systems Reseach Institute). (1989) Users Guide TIN. 1-1 9-19.

(Received March 4, 1994) 